\section{GOVERNMENT AND SCIENCE IN GREAT BRITAIN*}

By The Right Hon. SIR STAFFORD CRIPPS, P.C.

T

HE problem of the utilization of the scientist in the war effort is one that has been much discussed, though there is in reality no difference in the principles that should be applied in time of war and in time of peace. Whether it is for the purpose of winning victory in war, or of winning decent standards of living in peace, we should equally desire to utilize the highest degree of scientific knowledge in our industries.

There are two main factors in this problem : the provision of an adequate supply of skilled scientific staff, and the proper utilization of the scientific staff available. The neglect of scientific organization, and the failure to appreciate to the full the great part that science was bound to play in a modern war, led us, in the pre-war years, to neglect the organization of the scientific side of war. This we have attempted to remedy in the typical British way by improvising an ad hoc organization to deal with the various problems as they arose. We have not created a tidy, blue-print plan of scientific organization of the war effort, but have rather attempted to make the best use of our resources at those points where the resources seemed likely to produce the most valuable results in the quickest time. Hence our structure is one which it is easy to criticize as lacking method and orderliness, but, on the whole, it has, I believe, done as much for us as would any more tidy plan have accomplished, unless such a plan had been laid down and worked out well in advance. In sketching that organization it is perhaps easiest to start at the top.

There are five members of the War Cabinet who are, more or less, directly concerned with scientific matters and who thus represent in the War Cabinet some portion of our scientific effort. In addition to them, the Paymaster-General is a pure scientist and, in a very direct way, is able to assist and advise the Prime Minister who is, of course, Minister of Defence also, upon scientific matters.

In the War Cabinet, the Lord President of the Council is responsible for the Scientific Advisory Committee, which has wide terms of reference upon all scientific matters; and through that Committee the Cabinet is in touch with the Royal Society and with all the prineipal learned societies of Great Britain. The pooling of scientific knowledge throughout the Commonwealth is assisted by the Committee's association with the scientific liaison offices of the Dominions, and valuable contacts for the exchange of information have also been established with the appropriate bodies in the United States. The Lord President is also responsible for the Engineering Advisory Committee, which carries out similar functions in the field of engineering.

The Council referred to in the Lord President's title is, of course, the Privy Council, and this has long been associated with scientific research. It is the parent body to the Agricultural Research Council and the Medical Research Couneil, and to the Department of Scientific and Industrial Research, which originated in the War of 1914-18. This latter body is, in its turn, responsible for the National Physical Laboratory and many other research bodies and organizations; and

-Address before a conference of the Association of Scientifle Workers on "Planning of Science: in War and in Peace", held during January $30-31$. is in intimate association with other research associations both Governmental and industrial. All these are, as it were, centralized research and advisory bodies serving equally any Department.

Next we come to the Minister of Production. Last September three distinguished scientists were attached to the Minister of Production in an advisory capacity as full-time employees of the Government. These advisers are available to assist in all the Departments and can recommend measures for more effective coordination. They also act as a link with the British Central Scientific Office in Washington, which cooperates with the members of the supply missions in their joint working with American science. In addition, the Minister of Production is responsible for the Radio Board, which was set up recently to co-ordinate the whole of the work on radio in all the Services, including the Post Office. I preside, in my personal capacity, over this Radio Board on behalf of the Minister of Production.

The Minister of Labour and National Service is responsible for the Central Scientific Register and, in collaboration with the universities, the professional institutions, and the other Government departments concerned, as well as with organizations in Canada and the United States, he has seen to the training and mobilization of our scientific man-power. This has been a most difficult task, especially having in view the enormous growth of scientific personnel required in the Services for operating some of the newest devices.

The Minister of Home Security deals with the specialized scientific needs arising out of the problems of security against air attack, and is responsible for a research and experimental department concerned primarily with protection against the effects of bombing.

The fifth member of the War Cabinet is, of course, the Minister of Defence, and he is connected with the scientific side of the defence services for which the two Secretaries of State and the First Lord of the Admiralty are responsible. He also acts as chairman of the Anti-U-Boat Committee, which deals, among other things, with the scientific side of the anti-U. boat warfare.

So much for the highest level. Next we come to the various supply ministries and the fighting Services. There is a host of liaison eommittees at different levels between these different Ministries for the exchange of scientific information and experience, but each has its own scientific organization under a director of scientific research. The Ministry of Aircraft Production also has an important organization devoted to radio development, under the controller of communications equipment; though there are, in addition, many scientists operating outside the research sphere, both in development and production, and on operational planning.

One of the most marked developments during the War has been the growth of the application of purely scientific methods to operations, and there are now large scientific staffs in all three Services devoting their skill and energy to operational research.

\section{Co-ordination of Planning and Development}

The need for close linkage between the experience in the field and the planning and development of new weapons has been fully realized and methods for obtaining this have been gradually improved as the War has proceeded. Recently a new deputy chief of the Imperial General Staff has been appointed 
with the responsibility for ensuring that the Army requirements-and the means of fulfilling them-are projected against the background of modern science and research. In addition to being a member of the Army Council, he is a member of the Ministry of Supply Council and of a number of technical committees of that Ministry. He has under him a scientific adviser to the Army Council, who is also a member of the Scientific Advisory Council of the Ministry of Supply.

In the same way the chairman of the Aeronautical Research Committee is also a member of the Air Council and of the Ministry of Aircraft Production Supply Council, thereby giving a scientific link between the Air Ministry and the Ministry of Aircraft Production.

On the whole range of specialist committees, dealing with every aspect of the air programme, the Air Ministry, the Admiralty, and the Ministry of Aircraft Production are represented.

In the main testing establishments there is complete co-ordination between Service and civilian staff, who together carry the responsibility for testing. In a similar way the controller of communications in the Air Ministry is also controller of communications equipment in the Ministry of Aircraft Production and sits as a member of the Radio Board; as also does his vice-controller in my Ministry, who is also scientific adviser on telecommunications to the Secretary of State for Air. In this way we have been able to co-ordinate closely the work between the scientist and the Service user.

I have given these indications of the method of organizing scientific work and co-ordination in order to show that at many levels there is a close integration of the work.

This is not to say that, with ample staff and plenty of time, some better organization might not have been elaborated; ibut it is sufficient, perhaps, to indicate that the Government attaches the very highest importance to the proper utilization of our scientific effort and has gradually built up during the course of the War a machinery which, from the practical utility point of view, has enabled us in many branches of science to keep well ahead of our enemies.

\section{Government and Industry}

A great deal of our scientific strength in Great Britain is of course not in the employment of the Government at all but in the employ of private companies. Many of the great pre-War industrial organizations already had highly skilled research laboratories, which they have extended and which are now working whole-time on Government work.

It is not an easy matter to co-ordinate these organizations, as there has been, in some cases, a not unnatural reluctance for industrial research departments to pool the results of their research, though in other cases this pooling has been done most willingly and to the fullest extent. All these research organizations are, in one way or another, linked up with the various Supply Ministries, though we have not yet reached a perfect method of co-ordination and there is still, I believe, room for a better integration of this section of research and development.

There is one additional feature which I should mention, and perhaps I may do this especially in association with my own Ministry. We have an Aeronautical Research Committee with a number of sub-committees, the members of which are drawn from technical Government staffs and independent scientists with the necessary qualifications. From time to time the membership of these bodies is changed with the view of giving a freshness of outlook; but the difficulty is, of course, now being felt that so many scientists are either in Government or industrial employment that it is not easy to find independent scientists to serve.

In addition to this, there are advisory committees from the industries themselves consisting of engineers or scientists to whom specific problems may be referred or from whom advice may be sought upon the way to tackle definite questions.

I think that our main difficulty with regard to the proper utilization of the scientists in this war has been our failure to realize, at a sufficiently early stage, that this was going to be a truly scientific war, and that the battle would not be won merely by the physical ascendancy of our race but rather by the ingenuity of those who have been trained in our secondary schools, technical colleges, and universities. This realization has gradually grown upon the country and we are now fully alive to the fact that our survival and our victory depend to a great extent upon the output of our scientists and our research institutions, and that everything must be done to utilize to the full that very high degree of scientific intelligence which Great Britain undoubtedly possesses.

We need not be too critical of the exact manner in which that scientific knowledge is made available, provided only that it is made available and that there are no difficulties from those who still, perhaps, fail to realize fully how great a part science must play.

The scientists of Great Britain have undoubtedly achieved the most remarkable progress during the years of the War, but we must do everything in our power to maintain the lead that we have gained; I know that, as in the past our scientists have without stint given their services and their devotion to the country so, too, in the future we can look to them for new implements and new devices which will make our salvation certain and will hasten our victory.

\section{THE PLANNING OF SCIENCE}

$A$ $\mathrm{N}$ open conference on the "Planning of Science" was held in the Caxton Hall, London, on January 30 and 31, under the auspices of the Association of Scientific Workers. Perhaps the most significant comment on the subject was unspoken. For the first time those wishing to confer on the planning of science presented a substantial problem in London traffic control; 30 per cent of those wishing to attend the first session were-despite resort to a remarkably uncomfortable scale of overcrowdingunable to hear the discussion even from the lobbies; overflow accommodation, regrettably unavailable for the first session, had to be made available for the third; the least well-attended session was still a large gathering. No better index of the radical change in public interest need be sought.

Sir Robert Watson Watt, president of the Association of Scientific Workers, at the conclusion of his opening remarks, read a message of greeting dated from Moscow, January 29, 1943, from Vladimir Komarov, president of the Academy of Sciences of the U.S.S.R., and Nikolai Derzhavin, chairman of the Soviet Scientists' Anti-Fascist Committee and mem- 